\title{
Cloud Tree
}

\author{
Martin Power
}

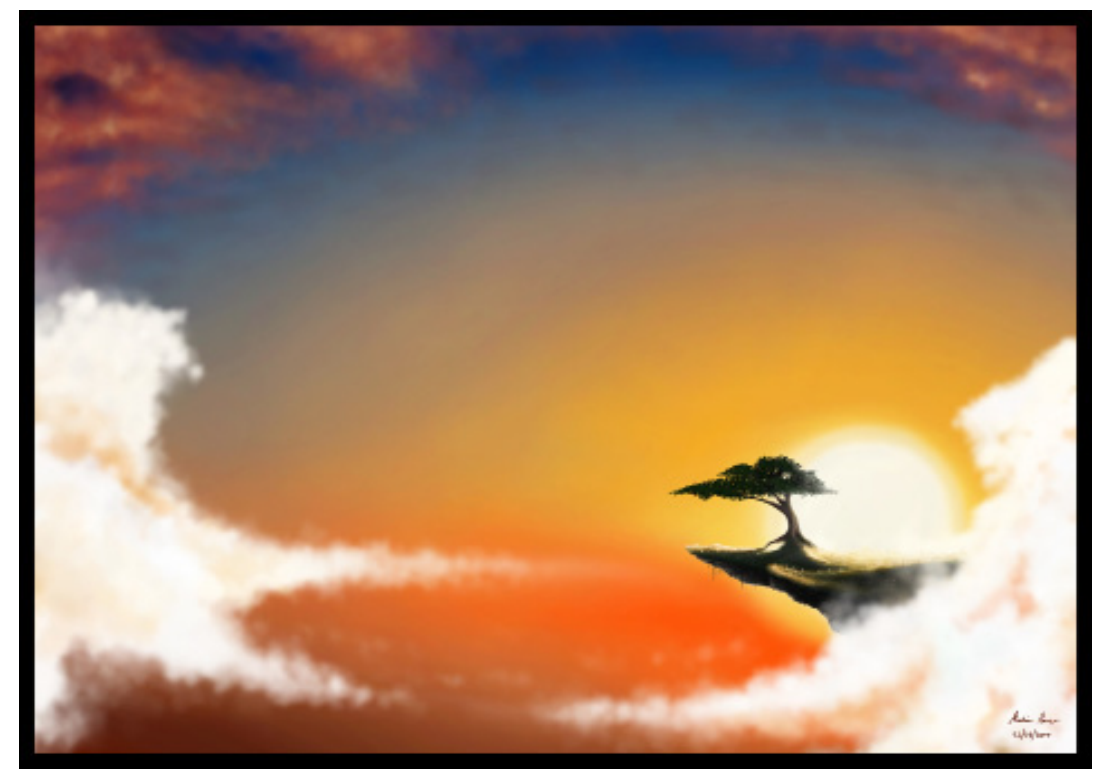

34 | Offset no. 11 